Jejaring Administrasi Publik, Vol. 13, No. 1, 2021, hal 58-69

\title{
Aplikasi Soft System Methodology (SSM) Untuk Pengembangan Strategi Pemberantasan Dalam Pandemi Covid-19 di Selandia Baru
}

\author{
Application of Soft System Methodology (SSM) for Development of \\ Eradication Strategies in the Covid-19 Pandemic in New Zealand
}

\author{
Adi Nuryanto \\ Analis Kebijakan pada Biro Kerja Sama dan Hubungan Masyarakat, Sekretariat Jenderal, \\ Kementerian Pendidikan, Kebudayaan, Riset dan Teknologi. \\ Email: adinuryanto@yahoo.com; adi.nuryanto@ui.ac.id
}

\begin{abstract}
The New Zealand government has ended the lockdown when it successfully suppressed the positive number of Covid-19 cases to zero for 17 consecutive days. The alert system level has been lowered from level 4 to level 1 within seven weeks. Restrictions on social activity have been loosened by paying attention to health protocol such as washing hands, not touching the face, coughing with the inner elbow and running health tests as well as contact tracing. The policy and strategies of Covid-19 handling in New Zealand consist of mitigation, suppression and elimination. The mitigation strategy seeks to control the number of positive cases so that the curve of the number of positive cases is flattened. The suppression strategy is intended to reduce the number of cases as minimum as possible. While the elimination strategy is intended to eradicate the Covid-19 virus. New Zealand is currently making efforts to eradicate Covid-19 disease which is the next challenge after successfully suppressing the number of positive cases of Covid-19 to zero in a long enough time. The development of an elimination strategy in the Covid-19 pandemic requires the determination of a scientifically robust definition of the elimination of Covid-19. This paper try to describe problems in developing an elimination strategy in the Covid-19 pandemic in New Zealand using the soft system methodology.
\end{abstract}

Keywords: elimination strategy, Covid-19, soft system methodology

\begin{abstract}
Abstrak
Pemerintah Selandia Baru telah mengakhiri lockdown saat berhasil menekan angka kasus positif Covid-19 hingga nol selama 17 hari berturut-turut. Tingkat sistem peringatan telah diturunkan dari tingkat 4 menjadi tingkat 1 dalam waktu tujuh pekan. Pembatasan aktivitas sosial telah dilonggarkan dengan tetap memperhatikan protokol kesehatan seperti mencuci tangan, tidak menyentuh wajah, menutup batuk dengan lengan dalam dan menjalankan test kesehatan dan penelusuran kontak. Kebijakan dan strategi penangangan Covid-19 di Selandia Baru terdiri dari pengawasan (mitigation), penekanan (suppression) dan pemberantasan (elimination). Strategi pengawasan berupaya mengendalikan angka kasus
\end{abstract}




\section{Nuryanto: " Aplikasi Soft System Methodology (SSM) Untuk Pengembangan Strategi Pemberantasan Dalam Pandemi Covid-19"}

positif sehingga kurva jumlah kasus positif melandai. Strategi penanggulangan dimaksudkan untuk menekan jumlah kasus seminimal mungkin. Sedangkan strategi pemberantasan ditujukan untuk membasmi virus Covid-19. Pengembangan strategi pemberantasan dalam pandemi Covid-19 memerlukan penentuan definisi yang kuat secara ilmiah mengenai pemberantasan Covid-19. Tujuan dari makalah ini adalah untuk dapat memberikan gambaran permasalahan dalam pengembangan strategi pemberantasan dalam pandemi Covid-19 di Selandia Baru menggunakan metode soft system methodology.

Kata kunci: strategi pemberantasan, Covid-19, soft system methodology

\section{Pendahuluan}

Selandia Baru akan segera mengakhiri peraturan lockdown akibat virus corona. Hal ini disebutkan oleh Perdana Menteri Selandia Baru pada tanggal 8 Juni 2020 setelah negara ini mencatat tidak ada kasus aktif. Satu-satunya kasus di negara itu telah pulih, yang berarti tidak ada kasus aktif Covid-19 di seluruh negeri itu. Otoritas kesehatan setempat juga mengkonfirmasi bahwa tidak ada kasus baru selama 17 hari berturut-turut. Selandia Baru merupakan negara berjumlah penduduk 4.951.500 jiwa. Jumlah kasus terkonfirmasi pada tanggal 14 Juni 2020 adalah sebanyak 1.154. Sedangkan jumlah sembuh sebanyak 1.482 dan jumlah kematian karena Covid-19 adalah 22 (Kementerian Kesehatan Selandia Baru, 2020).

Lockdown yang dijalankan selama tujuh minggu sejak 26 Maret 2020 telah membantu mengurangi tingkat penularan secara drastis. Hal ini menunjukkan efektivitas lockdown dengan tidak adanya lagi kasus aktif di negara itu. Pasien terakhir Covid-19 di Selandia Baru adalah seorang wanita berusia 50an tahun, tercatat tidak ada gejala selama 48 jam, sebelum diumumkan sembuh di Rumah Sakit St Margaret dan Rest Home di Auckland pada hari Senin, 8 Juni 2020.

Situasi tersebut sekaligus menjadi tonggak bagi pemerintah setempat untuk mengumumkan perpindahan status peringatan ke tingkat 1. Pada tingkatan ini, maka aktivitas sosial di ruang publik seperti pernikahan, pemakaman dan transportasi umum dapat dilanjutkan tanpa batasan. Namun perbatasan antar negara Selandia Baru akan tetap ditutup. 


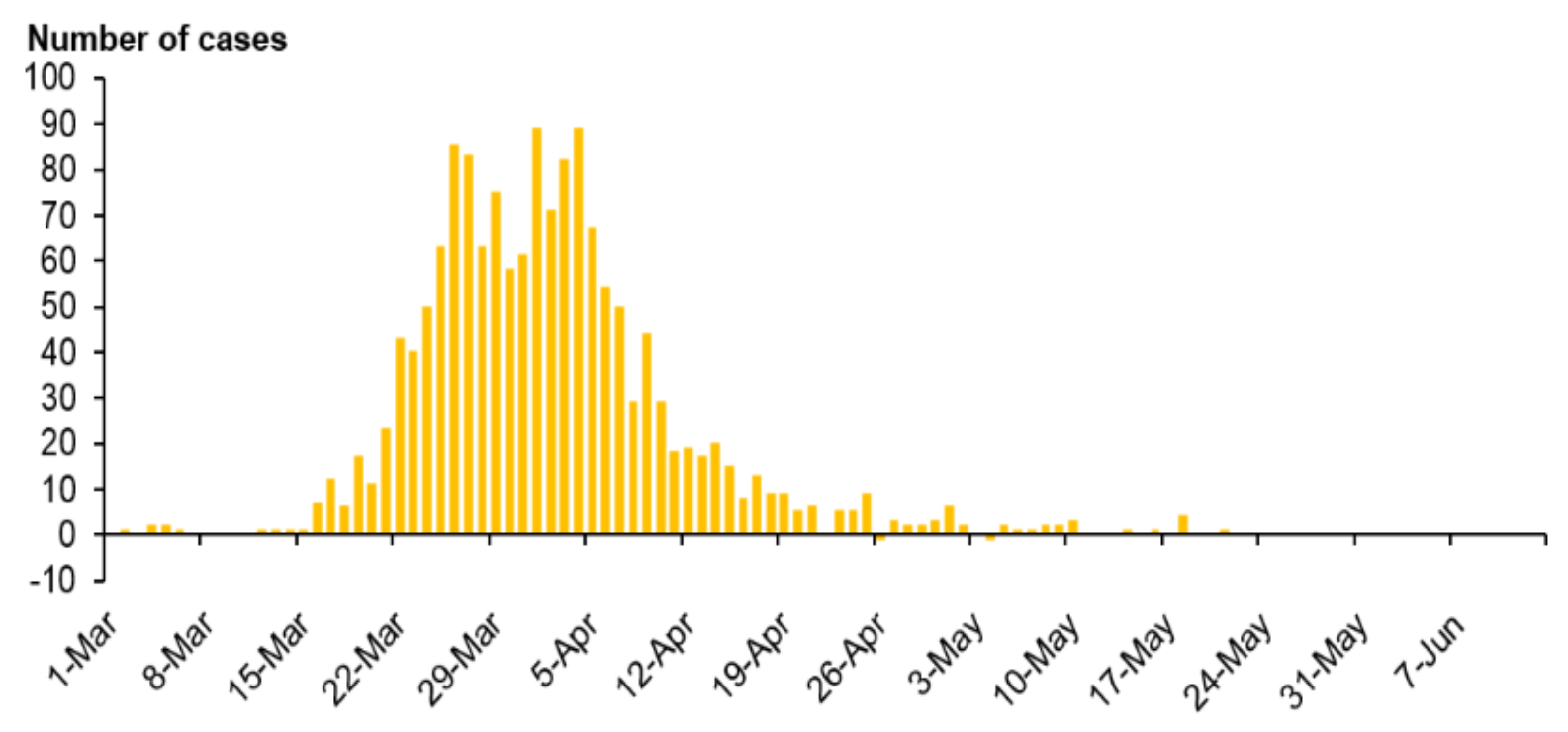

Gambar 1

Grafik jumlah harian kasus terkonfirmasi positif dan kemungkinan positif Sumber: Ministry of Health of New Zealand, 2020

Meskipun tingkat sistem peringatan telah diturunkan pada level 1, namun berbagai jenis protokol kesehatan tetap dijalankan di antaranya pembatasan di pintu perbatasan antar negara untuk meminimalkan risiko mengimpor kasus COVID-19 dari luar negeri. Pemerintah juga terus melakukan pengujian intensif untuk COVID-19, melakukan penelusuran kontak cepat untuk setiap kasus positif dan melakukan isolasi diri dan karantina. Sekolah dan tempat kerja sudah dapat dibuka namun dan harus dapat beroperasi dengan aman. Meskipun tidak ada batasan pada mobilitas per orangan namun masyarakat didorong untuk menyimpan catatan di mana mereka berada untuk keperluan penelusuran kontak jika diperlukan. Tidak ada pembatasan pada pertemuan-pertemuan di tempat umum maupun di tempat lainnya tetapi diharapkan untuk mencatat kehadiran sehingga dapat dimungkinkan untuk melakukan pelacakan kontak jika diperlukan. 


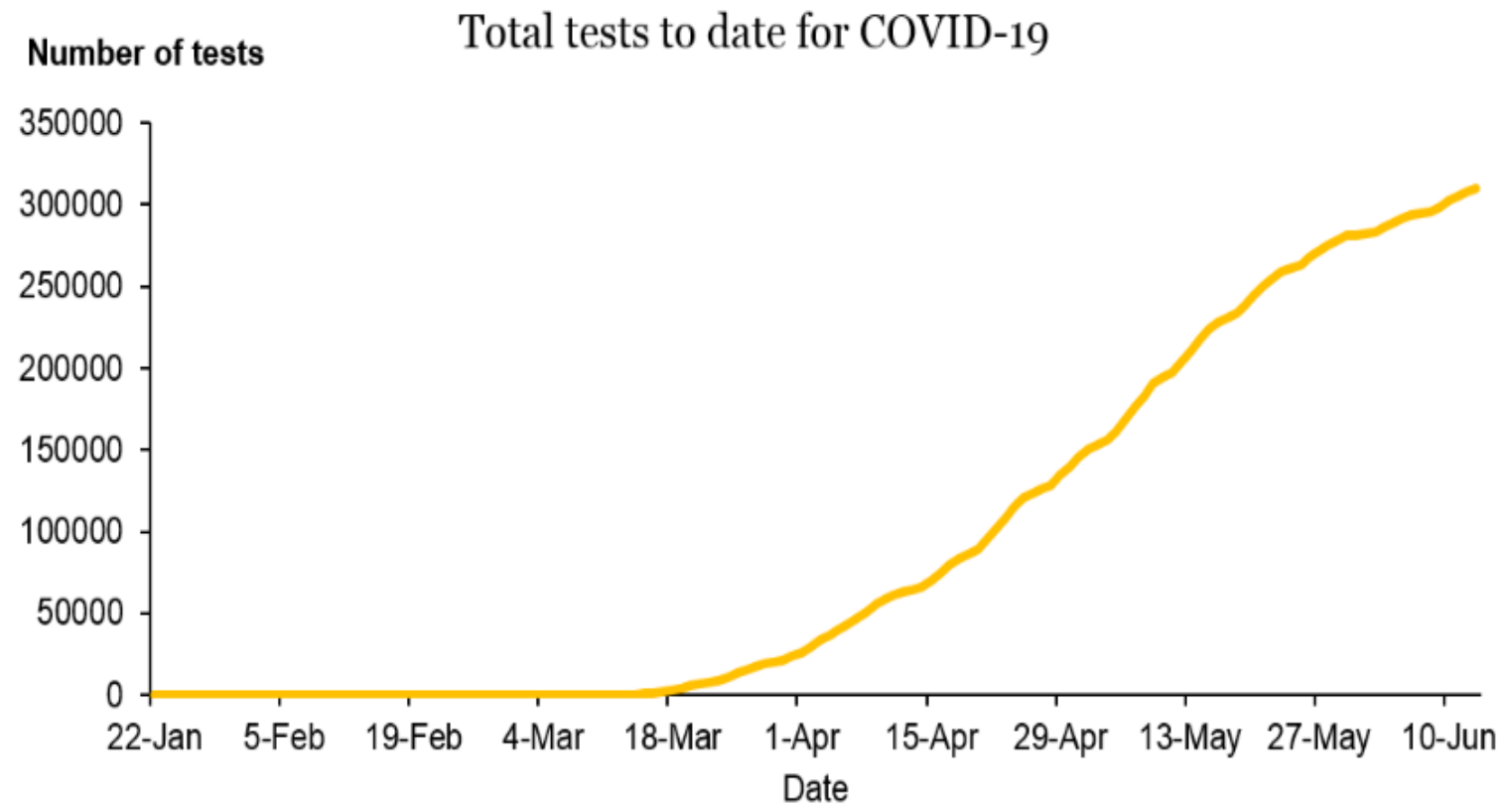

Gambar 2

Grafik jumlah total akumulasi pengujian Covid-19

Sumber: Ministry of Health of New Zealand, 2020

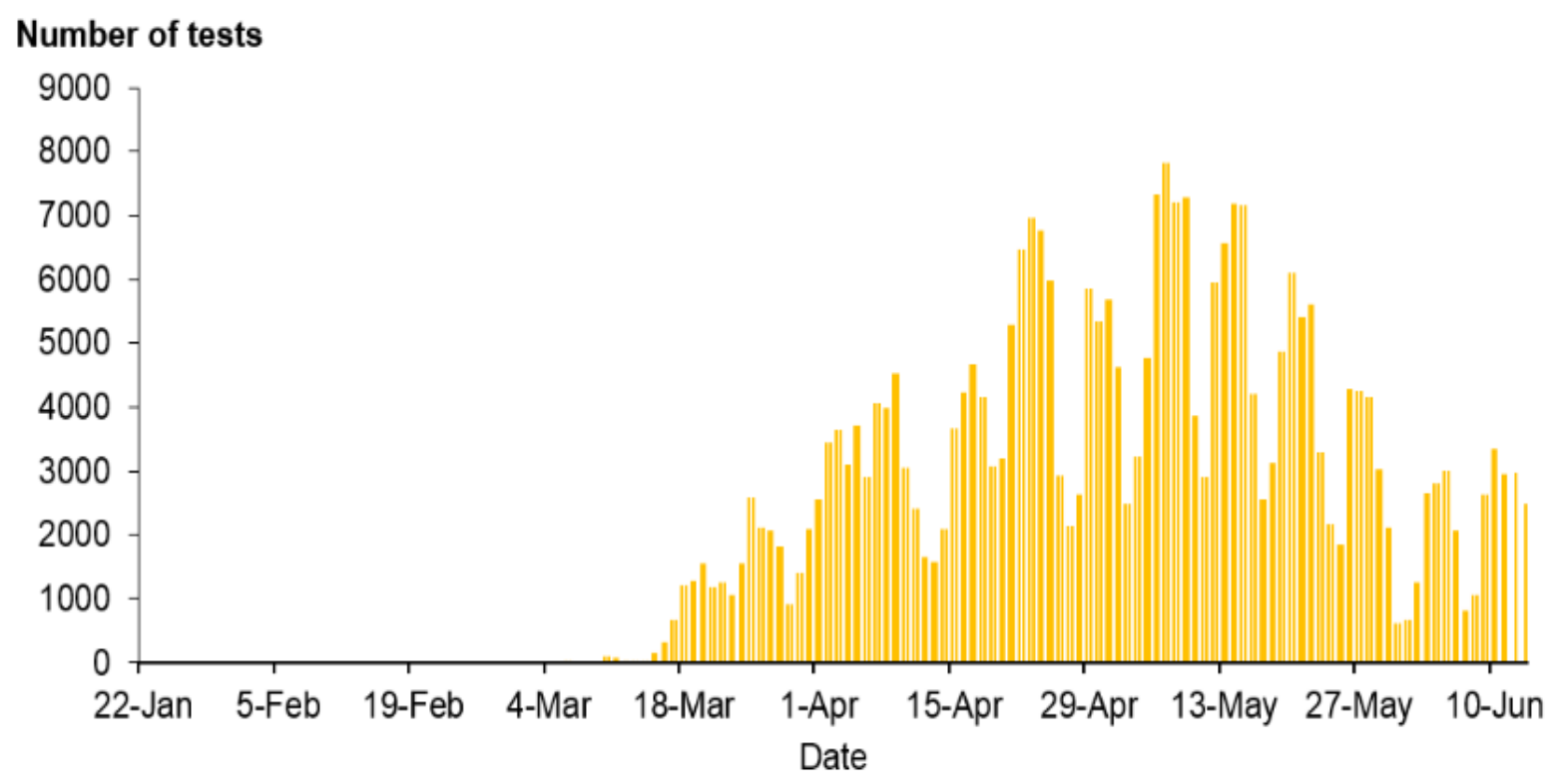

Gambar 3

Grafik jumlah harian pengujian Covid-19

Sumber: Ministry of Health of New Zealand, 2020 
Jumlah pengujian harian menunjukkan intensitas yang masih cukup tinggi untuk mengawasi kemunculan kasus positif. Berdasarkan total akumulasi pengujian dapat terlihat bahwa pemerintah terus melakukan pengujian untuk mengantisipasi kemunculan kasus baru.

\begin{tabular}{l|l|l|}
\hline As at 9.00 am, 8 June 2020 & Change in last 24 hours \\
\hline Number of confirmed cases in New Zealand & 1,154 & 0 \\
\hline Number of probable cases & 350 & 0 \\
\hline Number of confirmed and probable cases & 1,504 & 0 \\
\hline Number of recovered cases & 1,482 & 1 \\
\hline Number of deaths & 22 & 0 \\
\hline Number of active cases & 0 & -1 \\
\hline Number of cases currently in hospital & 0 & 0 \\
\hline
\end{tabular}

\section{Gambar 4}

Rangkuman jumlah kasus Covid-19 di Selandia Baru

Sumber: Ministry of Health of New Zealand, 2020

Pandemi COVID-19 menunjukkan adanya kemampuan virus menginfeksi penduduk dunia secara terus menerus. Virus ini sangat menular, dengan setiap kasus biasanya menginfeksi 2-3 lainnya. Akibatnya, potensi virus ini dapat menginfeksi sekitar 60\% penduduk dunia selama 1-2 tahun. Terdapat banyak ukuran resiko kesehatan, salah satunya adalah risiko fatalitas kasus (CFR). Angka 1\% CFR terhadap jumlah penduduk keseluruhan menunjukkan dampak risiko pada penduduk berusia 60 tahun ke atas dan mereka yang memiliki penyakit penyerta.

Di Selandia Baru telah dikembangkan beberapa pemodelan untuk meningkatkan akurasi perkiraan jumlah kasus dan kematian akibat infeksi Covid-19. Berbagai faktor dapat diperhitungkan untuk meningkatkan pemodelan termasuk tindakan masyarakat untuk melindungi diri mereka sendiri. Salah satu skenarionya adalah jika strategi pemberantasan Covid-19 ini gagal, jumlah kematian di Selandia Baru dapat mencapai 14.400 kematian.

Pengendalian pandemi yang tidak tepat akan meningkatkan ketidaksetaraan kesehatan yang tinggi. Seperti halnya flu musiman di Selandia Baru, risiko terutama terkonsentrasi pada orang tua dan bagi mereka yang memiliki komorbiditas parah. Sebagian kelompok orang rentan terhadap penyakit tertentu. 


\section{Nuryanto: " Aplikasi Soft System Methodology (SSM) Untuk Pengembangan Strategi Pemberantasan Dalam Pandemi Covid-19"}

Perencanaan penanganan pandemi di Selandia Baru dipengaruhi secara dominan oleh langkah-langkah sebagaimana diterapkan untuk menangani pandemi influenza. Perencanaan berfokus pada menunda kedatangan influenza, dan berbagai langkah-langkah untuk melandaikan kurva jumlah kasus positif pandemi.

Pendekatan lain yang merupakan variasi dari pendekatan mitigasi adalah strategi penekanan, di mana kurva dilandaikan ke titik dengan relatif sedikit kasus. Pendekatan ini memerlukan lockdown yang berkepanjangan yang dapat berlangsung selama berbulan-bulan sampai ditemukannya vaksin atau antivirus yang efektif. Tuntutan penggunaan pendekatan penekanan untuk menggantikan pendekatan mitigasi ini semakin meningkat karena sistem perawatan kesehatan telah kewalahan dalam mengatasi pandemi.

Namun COVID-19 bukanlah pandemi influenza. Potensi dan kapasitas pemerintah dan stakeholder terkait untuk mengendalikannya belum memadai. Perbedaan antara COVID19 dengan influenza sebagian besar pada fungsi biologi dan epidemiologi dari infeksinya. Infeksi COVID-19 memiliki masa inkubasi yang lebih lama (rata-rata 5-6 hari) dibandingkan dengan influenza (1-3 hari). Ciri ini memberikan kesempatan untuk mengidentifikasi dan mengisolasi kasus serta melacak dan mengkarantina kontak untuk meningkatkan keberhasilan penangangan, namun harus dilakukan dengan cepat dan efektif.

Salah satu kesuksesan metode penekanan, yang diperlukan untuk menuju metode eliminasi, dicapai oleh negeri Cina yang dapat membalikkan pandemi. Contoh yang relevan bagi Selandia Baru adalah yang dengan wilayah yang lebih kecil di Asia terutama Hong Kong, Singapura dan Korea Selatan.

Selandia Baru hanya memiliki jendela waktu yang sempit untuk mendefinisikan rencana penangangan sebelum pandemi tiba dengan kasus COVID-19 pertama pada 28 Februari. Pada awal April, terdapat lebih dari 800 kasus, yang mana hampir seluruhnya terjadi pada orang yang baru saja kembali dari luar negeri atau kontak dengan mereka. Namun, ada beberapa kasus penularan dalam masyarakat, yang cenderung bisa jadi lebih banyak dari angka yang dipublikasikan karena keterbatasan kapasitas pengujian yang difokuskan pada orang dengan riwayat perjalanan.

Karena itu Selandia Baru punya pilihan utama antara strategi mitigasi yang lebih populer atau pendekatan eliminasi yang lebih ambisius. Secara teknis, eliminasi adalah pemberantasan penyakit menular di tingkat negara atau regional, sedangkan istilah eradikasi dicadangkan untuk kepunahan global suatu organisme. Eliminasi penyakit telah diterapkan untuk berbagai manusia dan hewan penyakit menular, meskipun sering diperlukan vaksin yang efektif. 


\section{Jejaring Administrasi Publik, Vol. 13, No. 1, 2021, hal 1-17}

Pada pertengahan Maret tumbuh dukungan untuk strategi eliminasi. Pemerintah memperkenalkan sistem peringatan empat-tingkat pada 21 Maret dan negara saat itu ditempatkan pada tingkat 2 (pembatasan pertemuan yang mengumpulkan massa dan meningkatkan physical distancing). Negara ini kemudian meningkat statusnya dengan cepat ke tingkat 4 (secara luas digambarkan sebagai lockdown yang menutup semua sekolah, tempat kerja yang bukan urusan vital, pertemuan sosial dan restriksi perjalanan) yang berlaku mulai 25 Maret 2020. Situasi darurat nasional juga diumumkan, memberikan otoritas tambahan dan kekuatan untuk menegakkan tindakan pengendalian.

Strategi eliminasi ini merupakan perbedaan yang mendasar dibandingkan dengan strategi penanganan penyebaran pandemi influenza. Dengan strategi mitigasi, respon dan tindakan semakin meningkat atas kasus yang muncul dan menuntut intervensi lebih seperti penutupan sekolah dan memperkenalkan istila melandaikan kurva. Strategi pemberantasan membalikkan urutan penanganan terhadap kemunculan kasus baru dan penularan lokal COVID-19.

Pendekatan pemberantasan ini memiliki fokus yang kuat pada kontrol perbatasan wilayah, yang jelas lebih mudah diterapkan untuk negara pulau seperti Selandia Baru. Pendekatan ini juga menekankan isolasi dan karantina kasus untuk memutus rantai penularan. Jika langkah-langkah ini gagal dan ada bukti transmisi masyarakat secara luas, maka diperlukan tindakan utama (physical distancing, pembatasan perjalanan dan karantina massal atau lockdown) untuk memutus dan menghentikan rantai penularan.

Strategi eliminasi memiliki manfaat lebih dibandingkan dengan strategi mitigasi. Jika strategi ini dimulai lebih awal maka akan berakibat pada lebih sedikit jumlah kasus positif dan kematian. Jika itu sukses maka akan membawa manfaat sosial dan ekonomi yang dihasilkan untuk Selandia Baru. Strategi eliminasi juga dapat mendukung Pulau Pasifik tetangga untuk tetap bebas dari virus ini jika mereka melonggarkan pengendalian perbatasan.

Strategi eliminasi juga memiliki risiko dan mungkin cukup besar risikonya. Untuk membuat strategi ini berjalan sebagai mestinya, Selandia Baru tidak memiliki alternatif selain meningkatkan tindakan menjadi lockdown nasional, yang dimaksudkan utamanya untuk memberikan waktu yang cukup untuk melakukan tindakan-tindakan pengendalian kunci. Lockdown nasional diperlukan untuk memastikan populasi akan cepat beralih ke dalam perilaku physical distancing untuk membatasi penyebaran dan pemutusan ranti penularan. Perencanaan pengendalian penyakit di Selandia Baru tidak mengacu atau dipengaruhi oleh cara penanganan pandemi SARS, di mana banyak negara Asia mengalaminya, di mana kesadaran masyarakat atas konsep-konsep seperti karantina dan isolasi sangat terbatas. 


\section{Nuryanto: " Aplikasi Soft System Methodology (SSM) Untuk Pengembangan Strategi}

Pemberantasan Dalam Pandemi Covid-19"

\section{Metode Penelitian}

Soft System Methodology (SSM) dikembangkan untuk menghadapi situasi di mana setiap orang memiliki persepsi sendiri mengenai dunia dan membuat justifikasi menggunakan nilai-nilai mereka sendiri. SSM didasarkan pada metodologi action research yang ditujukan untuk menggali, mempertanyakan dan mempelajari situasi permasalahan dengan berpikir sistem agar dapat menemukan solusi permasalahan. Tahapan dalam SSM yang perlu dilakukan untuk pengembangan strategi pemberantasan dalam pandemi Covid-19 di Selandia Baru ini adalah sebagai berikut.

a) Langkah pertama berupa adalah analisis situasi terhadap konteks permasalahan, dalam hal ini adalah pengembangan strategi pemberantasan dalam pandemi Covid19 di Selandia Baru.

b) Langkah kedua dilakukan dengan mengidentifikasi permasalahan dan pihak-pihak yang berkepentingan dan peran masing-masing dan dituangkan dalam bentuk Rich Picture.

c) Langkah ketiga adalah menentukan peran setiap pihak dalam pendekatan CATWOE (Client or Customers, Actors, Transformations, World view, Owner dan Environment constraint).

d) Langkah keempat yaitu merancang model konseptual yang menjelaskan hubungan antar aktivitas dan input-proses-output.

e) Langkah kelima adalah membandingkan antara model konseptual hasil perancangan dengan dunia nyata.

f) Langkah keenam adalah mengidentifikasi kemungkinan perubahan model konseptual. Pendapat pakar akan berguna dan dapat mengubah model untuk mendapatkan gambaran yang lebih sesuai dengan dunia nyata.

g) Langkah ketujuh yaitu melakukan tindakan untuk perbaikan model yang telah dikembangkan yang dilakukan secara iteratif.

\section{Hasil dan Pembahasan}

\section{Tahap pertama - Situasi Problematik}

Strategi lockdown memiliki dampak dan biaya sosial dan ekonomi yang besar, dan menjadi semakin sulit terutama bagi orang-orang dengan sumber daya paling sedikit. Tindakan pemerintah harus termasuk mendukung kelompok ini, termasuk dukungan paket ekonomi dan pembatasan berkembangnya pinjaman. 
Tahap kedua - Rich Picture

Pada tahap kedua dilakukan identifikasi permasalahan dan pihak-pihak yang berkepentingan dan peran masing-masing dan dituangkan dalam bentuk Rich Picture sebagaimana gambar 5 .

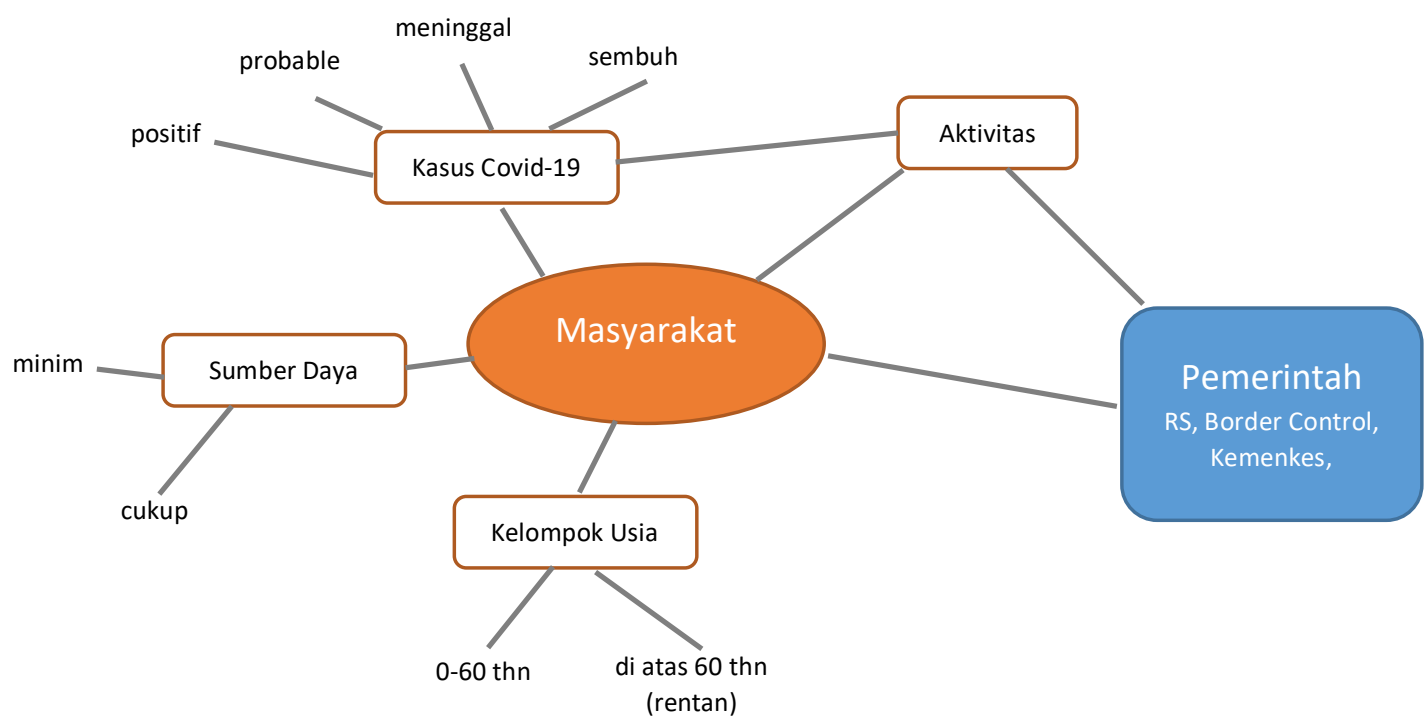

Gambar 5

Rich Picture

Sumber: primer peneliti

Tahap ketiga - Root Definitions

Pada tahap ini ditentukan root definition berdasarkan Rich Picture dengan mendefinisikan CATWOE sebagai berikut.

Client or Customers : Masyarakat dengan berbagai kategori/kelompok, pelaku usaha

Actors : Pemerintah, Rumah Sakit, Kemenkes, Pos Perbatasan

Transformations : Pengembangan strategi pemberantasan Covid-19

World view : Kesehatan masyarakat

Owner : Pemerintah 


\section{Nuryanto: " Aplikasi Soft System Methodology (SSM) Untuk Pengembangan Strategi Pemberantasan Dalam Pandemi Covid-19"}

Environment constraint
: Aktivitas masyarakat, masyarakat kelompok rentan secara kesehatan maupun ekonomi, aktivitas ekonomi, keterbatasan anggaran pemerintah

\section{Tahap keempat - model konseptual}

Strategi lockdown memiliki dampak dan biaya sosial dan ekonomi yang besar, dan menjadi semakin sulit terutama bagi orang-orang dengan sumber daya paling sedikit. Tindakan pemerintah harus termasuk mendukung kelompok ini, termasuk dukungan paket ekonomi dan pembatasan berkembangnya pinjaman.

Pemberantasan adalah sebuah strategi pengendalian penyakit menular, dan Selandia Baru dapat belajar dari pengalaman dalam memberantas penyakit menular pada manusia dan hewan. Secara khusus terdapat pelajaran yang bisa dipelajari dari strategi pemberantasan campak dan rubella, meskipun dengan perbedaan bahwa tidak adanya vaksin yang efektif untuk COVID-19. Pengalaman masa lalu telah mengajarkan tiga faktor yang sangat penting untuk keberhasilan eliminasi : 1) sistem surveilans epidemiologi dan laboratorium berkinerja tinggi; 2) sistem kesehatan publik yang efektif dan adil yang dapat memastikan mobilisasi intervensi yang seragam dan kuat untuk semua lapisan masyarakat, termasuk kelompok terpinggirkan (difokuskan pada diagnosis, isolasi kasus dan karantina dari kontak); dan 3) kemampuan untuk mempertahankan keberlanjutan program nasional dan memperbarui strategi untuk mengatasi masalah yang muncul.

\section{Tahap kelima - membandingkan model dengan dunia nyata}

Elemen penting dari strategi eliminasi COVID-19 meliputi beberapa hal, di antaranya kontrol perbatasan dengan kapasitas dan kualitas karantina bagi wisatawan yang datang. Perlu dilakukan deteksi kasus secara cepat yang diidentifikasi dengan pengujian secara luas, diikuti oleh isolasi kasus secara cepat, dengan pelacakan kontak yang cepat dan karantina untuk mereka yang kontak dengan kasus positif. Menjaga pola hidup bersih dan sehat secara intensif (etika batuk dan mencuci tangan) dan penyediaan fasilitas kebersihan tangan di tempat umum. Melakukan physical distancing yang intensif, yang diimplementasikan sebagai lockdown (peringatan level 4) yang meliputi penutupan sekolah dan tempat kerja, pembatasan mobilisasi dan perjalanan, dan langkah-langkah yang ketat untuk mengurangi kontak di ruang publik, dengan kemungkinan dapat melonggarkan tindakan ini jika strategi eliminasi sudah berjalan dengan baik. Strategi komunikasi yang terkoordinasi dengan baik 
untuk menginformasikan pada masyarakat tentang langkah-langkah pengendalian dan apa yang harus dilakukan jika kondisi mereka menjadi tidak enak badan, dan memperkuat promosi pesan kesehatan.

\section{Kesimpulan}

Penggunaan soft system methodology (SSM) untuk pengembangan strategi pemberantasan dalam pandemi covid-19 di Selandia Baru disimpulkan sebagai berikut lockdown memiliki dampak dan biaya sosial dan ekonomi yang besar.kebijakan tersebut menyulitkan terutama bagi orang-orang dengan sumber daya paling sedikit. Pemerintah perlu untuk memberikan dukungan paket ekonomi dan pembatasan berkembangnya pinjaman. Elemen penting dari strategi eliminasi COVID-19 meliputi beberapa hal, di antaranya kontrol perbatasan dengan kapasitas dan kualitas karantina bagi wisatawan yang datang. Perlu dilakukan deteksi kasus secara cepat yang diidentifikasi dengan pengujian secara luas, diikuti oleh isolasi kasus secara cepat, dengan pelacakan kontak yang cepat dan karantina untuk mereka yang kontak dengan kasus positif. Langkaha lain dengan menjaga pola hidup bersih dan sehat secara intensif (etika batuk dan mencuci tangan) dan penyediaan fasilitas kebersihan tangan di tempat umum. Melakukan physical distancing yang intensif, yang diimplementasikan sebagai lockdown (peringatan level 4) yang meliputi penutupan sekolah dan tempat kerja, pembatasan mobilisasi dan perjalanan, dan langkah-langkah yang ketat untuk mengurangi kontak di ruang publik, dengan kemungkinan dapat melonggarkan tindakan ini jika strategi eliminasi sudah berjalan dengan baik.

\section{Daftar Pustaka}

Baker, Michael G; Kvalsvig, Amanda; Verrall, Ayesha J; Telfar-Barnard, Lucy; Wilson, Nick.(2020) The New Zealand Medical Journal (Online); Christchurch Vol. 133, Iss. 1512, (Apr 3, 2020): 10-14.

Cousins, S. (2020). New Zealand eliminates COVID-19. The Lancet, 395(10235), 1474. doi:10.1016/s0140-6736(20)31097-7

Baker, M., Wilson, N.; Hendy,S. Skegg,D.(2020). The need for a robust scientific definition for the elimination of COVID-19 from New Zealand, Public Health Expert, 05/05/2020

Baker,M and Wilson,N.(2020). New Zealand Hits Zero Active Coronavirus Cases. Here Are 5 Measures to Keep It That Way .https://www.usnews.com/news/best- 
Nuryanto: " Aplikasi Soft System Methodology (SSM) Untuk Pengembangan Strategi Pemberantasan Dalam Pandemi Covid-19"

countries/articles/2020-06-08/new-zealand-hits-zero-active-coronavirus-cases-hereare-5-measures-to-keep-it-that-way

New Zealand Government, Alert system overview, https://uniteforrecovery.govt.nz/covid19/covid-19-alert-system/alert-system-overview/\#alert-level-1-\%E2\%80\%94-prepare

Ministry of Health of New Zealand, Covid-19 - current cases, https://www.health.govt.nz/our-work/diseases-and-conditions/covid-19-novelcoronavirus/covid-19-current-situation/covid-19-current-cases

Population.https://www.stats.govt.nz/topics/population 